\title{
FRAMING SPACE AND TIME IN THE CITY: URBAN POLICY AND THE POLITICS OF SPATIAL AND TEMPORAL SCALE
}

\author{
EUGENE J. McCANN \\ Ohio State University
}

\begin{abstract}
This article seeks to analyze urban politics through the lens of the social constructionist approach to scale. This approach views scale not as a set of pre-given, natural, and immutable levels upon which social life occurs. Rather, it regards scale as a fluid context for and product of power relations in society. The article argues that urban politics is frequently characterized by political strategies that frame reality in terms of scale. Agents of the state, capital, and civil society all engage in the politics around competing scalar framings. As a result, the politics of scale has important but contingent material consequences. The article illustrates these points through a case study of the politics that surrounded the development of a new neighborhood planning initiative in Austin, Texas in the late 1990s. Based on this case study, the article also argues that while geographers studying the politics of scale tend to explain it solely in terms of spatial scale, scalar politics in the urban context frequently combines framings of spatial and temporal scale. This simultaneous framing of space and time in the city has important, if sometimes unpredictable, implications for policy and politics.
\end{abstract}

$\mathbf{T}$ he reconfiguration of urban governance in recent decades has, among other things, entailed a reshuffling of the locations of power among the institutions of the state, capital, and civil society and the opening up of the urban policy-making process. An important aspect of this has been capital's increased degree of direct control over the formulation of urban policy, e.g., through public-private partnerships (Harvey, 1989). This ongoing restructuring is also associated with changes in the ways that groups beyond the state and capital are involved in policy formulation. In this regard, there has been a growing attention to, or at least rhetoric of, broad-based inclusion in the US urban policy-making arena. Ideally, this means that neighborhood organizations, environmental campaigners, advocates for the poor, and many other activist groups are to have a seat at the decisionmaking table. This goal has led local government staff and urban planners to adopt a wide range of alternative decision-making techniques, such as consensus-based processes and collaborative visioning (Walzer, 1996; Woodmansee, 1994). This changing policy-making

*Direct correspondence to: Eugene J. McCann, Department of Geography, Ohio State University, Columbus, OH 43210-1361.E-mail: mccann.80@osu.edu

JOURNAL OF URBAN AFFAIRS, Volume 25, Number 2, pages 159-178.

Copyright (C) 2003 Urban Affairs Association

All rights of reproduction in any form reserved.

ISSN: 0735-2166. 
context means that political actors intent on shaping policy face changing opportunities and constraints that often necessitate the modification of their arguments and political practices. The study of urban politics focuses on uncovering these changing political practices and identifying the key elements of change.

My purpose is to consider how a burgeoning literature in critical human geography can provide useful insights into the contemporary practice of urban politics. This geographical literature is concerned with how spatial scale (the local, national, global, etc.) is socially constructed and, therefore, imbued with power. Scale is conceived not as a set of pre-given and immutable levels upon which human life is lived, but as a socially constructed way of representing reality and dividing the world for specific political purposes (Marston, 2000). This social constructionist approach focuses on the political work that scale (or the idea of a world divided into scales) can perform and the contests that surround attempts to divide the world into one set of scales as opposed to another. From this perspective, the politics surrounding changes in contemporary urban policy-making is a politics of scale. In this politics, scale is not a neutral background. Rather, it is a discursive frame used by competing interests to define or redefine the appropriate location of political power and the territorial extent of specific policies and regulations (Delaney \& Leitner, 1997).

The term discursive frame refers to the process through which interest groups involved in urban politics seek to convince others of the merits of their particular understanding of how the world is, how it should be, and the policies that will make it better in the future. Social movement theorists argue that this political persuasion works through framessimplifications of the world that selectively identify and attach meaning to certain actions, experiences, and events - for the purpose of influencing politics and policy (Snow \& Benford, 1992; Tarrow, 1992; and see Nash, 2000). For instance, Tarrow (1992) argues that the 1960s civil rights movement was successful in creating a broad base of support among blacks and middle class whites because it framed the complex social and political landscape of the decade in terms of a simple and powerful theme - rights - that resonated with shared values held by the majority of coalition members. The emphasis on rights as a meaningful theme was a discursive strategy because discourse "refers to all the ways in which we communicate with one another, to that vast network of signs, symbols, and practices through which we make our world(s) meaningful to ourselves and to others" (Gregory, 1994a, p. 11, Barnes \& Duncan, 1992). Discursive framing draws on certain aspects of materiality and experience of everyday life to focus the attention of a wide range of people on a common concern so as to achieve a particular political purpose.

Drawing on a case study of the implementation of a neighborhood planning framework in Austin, Texas, I argue that urban politics is frequently characterized by the discursive framing of reality in terms of scale. The politics emerge through various actors' attempts to frame reality in different ways that promote their interests and enable them to implement policy and mobilize politically. As a result, the politics of scale has important but contingent material consequences. I also suggest that the politics of scale is about more than spatial scale (with which geographers have been most concerned in recent years). Discursive framings of scale in US cities are articulated simultaneously in spatial and temporal terms where discussions of "our neighborhood" and "our city" are interwoven with appeals to time of residence in a neighborhood and longstanding cultural connections to a city. This framing of space and time in the city has important, if unpredictable, implications for policy and politics.

The next section will present a more detailed account of contemporary changes in urban governance and their relationships to constructionist perspectives on scale. The subsequent section will provide some details of the rapidly changing context in which the 
politics of scale has played out in Austin. Following this, the city's neighborhood planning program is examined as a new scale of policy-making characterized by a reorganization of the traditional decision-making procedures. This section also discusses one of first neighborhoods to be replanned (the predominantly low-income, Latino, East César Chávez neighborhood) and the politics that developed in relation to the new program. The final section of the article examines in more detail the politics of scale surrounding the neighborhood planning program, focusing on the simultaneous spatial and temporal scalar framings employed by one group of activists.

\section{RESTRUCTURING AND RESCALING: URBAN POLITICS AS A POLITICS OF SCALE}

Before describing the case study, I discuss the theoretical context in which the article is set by outlining two aspects of the ongoing restructuring of urban governance: 1) the privatization of policy-making power, and 2) the related rise of new forms of decisionmaking. I then discuss the social constructionist perspective on scale and suggest how it might be linked to a study of urban politics.

A key concern of urban politics literature since the 1980s has been to theorize how contemporary local policy is formulated and the affects that policy has on the character of local political economies and built environments (Cox \& Mair, 1988, 1989; Fainstein, Fainstein, Hill, Judd, \& Smith, 1987; Harvey, 1989; Logan \& Molotch, 1987; Stone, 1989). A significant aspect of these literatures has been their focus on the contested and complex processes through which government has been replaced by governance in cities of the western industrialized world. This shift, recently characterized as the "destatization of the political system" (MacLeod \& Goodwin, 1999, p. 505), entails a lessening of direct state control over the formulation and implementation of social and economic policy. Accordingly, there is a shift in the control of policy-making towards agents of private business and civil society with state agents increasingly performing a facilitative function (Harvey, 1989; Stoker, 1995; Stone, 1989).

Part of this politics of public-private coalition building entails the legitimation of policy decisions through rhetoric of openness and inclusion of civil society in decisions formerly made by the state and capital. Concrete expressions of this rhetoric include the development of alternative dispute resolution techniques, consensus-based decision-making processes, and the currently fashionable idea of collaborative visioning, (Helling, 1998; Lake, 1994, 1996; McCann, 1997, 2001; Myers \& Kitsuse 2000; Oregon Visions Project, 1993; Shipley \& Newkirk, 1999; Walzer, 1996; Woodmansee, 1994). In the context of urban planning in the US, these changes have been manifested in a general shift away from expert-led planning procedures toward consensus-driven, participatory approaches. New forms of decision-making emphasize the importance of lay-planners (ordinary citizens rather than expert bureaucrats) in shaping the future of cities.

A change in the scale at which urban planning policy is formulated and implemented is related to the emphasis on participatory planning. There has been a shift in focus from the citywide scale, which was the concern of comprehensive planning, to the scale of the small area or neighborhood (Dear, 1986, 1989; Filion, 1996; McGuirk, 1994; Winter \& Brooke, 1993). However, as the neighborhood planning literature suggests, there is diverse array of approaches to planning at this scale (Checkoway, 1984; Jones, 1990; Peterman, 2000). This dual movement toward participatory policy-making and neighborhood planning constitutes a significant change with important implications for urban politics. 


\section{The Constructionist Understanding of Scale and its Political Implications}

A major question in urban politics is how each coalition of political actors constructs a relatively consistent discourse, or discursive frame, on the future of the city that resonates with their own political ideology and is persuasive to a wider constituency. These discourses strategically and instrumentally highlight certain aspects of the place and its political, economic, and social context. For instance, as Wilson and Wouters (2002) argue, certain actors might construct a political discourse that represents a city's economy as sick and suggests that it can only be cured through the intervention of certain entrepreneurs who can act as civic salvationists. This discursive framing of reality creates a vision of the future that, through its very construction, places other possible visions outside the bounds of discussion. Thus, while the framing is enabling for those who construct it, it limits other actors' ability to influence urban policy.

Discourses in urban politics frequently employ geographical scale as a framework for creating a particular vision of the future of a place. In a recent review of the relevant constructionist literature on scale, Marston (2000) identified three foundational arguments. First, scale is not externally, or ontologically, pre-given. Instead, the "differentiation of geographical scales establishes and is established through the geographical structure of social relations" (Smith, 1992, p. 73). Scale is "the focal setting at which spatial boundaries are defined for a specific social claim, activity, or behavior" (Agnew, 1997, p. 100). Second, while scale is a way of framing reality and setting boundaries for action through discursive means, the social production of scale is not merely rhetorical. Rather, it is fundamental to the historical, geographical, and material constitution of society and everyday life. Marston's (2000) third point is that framings of scale are often contradictory and never permanent. As such, they are frequently contested and struggled over, or as she puts it, "scale construction is a political process endemic to capitalism, the outcome of which is always potentially open to further transformation" (p. 221).

Marston's last point resonates with the work of a number of scholars who have conceptualized contemporary restructuring processes in terms of the rescaling of the state and capital. By rescaling, they mean the process in which policies and politics that formerly took place at one scale are shifted to others in ways that reshape the practices themselves, redefine the scales to and from which they are shifted, and reorganize interactions between scales (Brenner, 2000; Jessop, 1994; Swyngedouw, 1997). An associated theme in this literature is the notion of a scalar fix (Brenner, 1998a; Jonas \& Ward, 2002). The concept has two related connotations: 1) fix in terms of stability and order as opposed to flux and fluidity, and 2) fix in terms of problem solving. Scalar fix refers to the social and political process of (re)defining scales to facilitate the accumulation of capital, efficient social redistribution, and effective governance. While particular interests are served by the reorganization of accepted scalar hierarchies, there is a necessity for certain scalar territorial formations to be solidified, or fixed, in order to provide what Brenner (1998a) refers to as an infrastructure for economic development. Therefore, even in a time of restructuring when scales could be seen as relatively fluid, the process of creating new scales within which policy will be formulated and implemented entails an attempt to create a scalar fix, or organizational stability, to facilitate a certain form of development.

The need for a new scalar fix is the result of problems created by previous politicaleconomic arrangements. For instance, a particular set of urban policies related to land use, infrastructure, or the provision of social services that have been organized at the urban scale, may become politically and economically untenable for various reasons. As this crisis develops, there is likely to be a search for solutions, including a possible 
reorganization of the scales at which certain policies are located in order to "overcome the problems of governance and social redistribution arising from uneven geographical development" (Jonas \& Ward, 2002, p. 381). Attempts to implement metropolitan governance would be an example of this rescaling. This is the related connotation of the scalar fix as a solution to crisis. While a great deal of recent literature has focused on the ways in which contemporary scalar fixes tend to be oriented toward the creation of new spatial scales of governance above the urban scale (Jonas, 1994; Jonas \& Ward, 2002), I argue it is also possible to see the creation of new scalar fixes that incorporate scales below the urban (such as the neighborhood) into new policy infrastructures.

In this article I apply the constructionist perspective on scale to US urban politics. The urban context has not been neglected in the literature on scale. Numerous authors have tied their discussions of globalization to certain so-called global cities (Brenner, 1998b; Taylor, 2000). Cox (1998a) used a discussion of scale to elucidate the politics of local economic development (and see Cox, 2002 for a critique of the international emphasis in contemporary scale literatures). Smith (1992, 1993) argues that scale construction might be felt most intensely at the urban scale and shows how less powerful social groups can construct their own politics of scale in the urban context. These contributions notwithstanding, there is still room for analysis of how the politics of scale plays out in cities.

Three specific points can be drawn from this literature that relate directly to the politics surrounding urban policy-making. First, the politics of scale is constituted by discursive practices that "can be seen as practical efforts to persuade or convince; to create in the minds of others a kind of mental map or image" (Delaney \& Leitner, 1997, p. 94). These practices are designed to convince a constituency that particular policies are best implemented and discussed at a specific scale and not at others (for a similar argument see Cox, 1998a). Urban politics as a politics of scale entails conflicting appeals to the worldviews of particular constituencies that point out the material changes in their lives that will be produced by a certain scalar fix and the changes in economic or institutional practices that this reorganization will entail.

Second, central to the constructionist view of scale is the point that "one scale... only makes sense in relation to others" (Agnew, 1997, p. 100). In the urban context, political argumentation frequently refers to processes working at scales other than the city itself. The power being struggled over in urban politics is the power to persuade that particular scalar relationships are imperative to the successful functioning of the city's economy and society and will enhance the well being of its residents (Wolman \& Goldsmith, 1992). For example, as local business and political elites promote their development agendas, they often invoke a discourse of globalization in which only cities that make themselves attractive to inward investment can survive. This discourse represents the locality as facing a hard and unavoidable set of truths imposed by the global scale. It legitimizes neoliberal policies that have unequal social consequences, such as maintaining relatively low wage levels and allowing the public sector to assume the risks associated with speculative development (Cox \& Mair, 1988; Harvey, 1989).

A third point is that processes of rescaling necessarily entail a disruption and recomposition of the networks of power that tie political actors together within and across scales. The development of a new scalar fix means that new opportunities emerge for political action as others are curtailed. As established political opportunity structures open up, the relative influence of the state in policy formation declines. Under these circumstances, restructuring cannot be assumed to wholly benefit any one interest group. Its outcomes are contingent on the political strategies and opportunities acted upon in certain situations 
within a larger context. As a result, the study of urban politics needs to investigate these strategies and the use of scale as a framework for political persuasion.

The following case study describes political strategies and experiences of various actors as they negotiate changes in the formulation and implementation of new planning policies. The study is based on eight weeks of fieldwork in Austin, Texas during October and November 2000. The research had three components: 1) semi-structured interviews with key informants, 2) direct observation of planning meetings, and 3) archival research. Each component was intended to elicit an understanding of how key actors in contemporary policy-making experienced the process, how they understood their role in policy-making, and how they formulated political positions in relation to new urban policies. Eighteen interviews, ranging from 45 minutes to two hours, were conducted with private-sector economic development leaders, individuals responsible for the neighborhood planning and related initiatives, and neighborhood activists who were either engaged in the planning process or were arguing against it. The interviews were complemented by direct observation of seven meetings related to the implementation of neighborhood planning. These included one of the later leadership team meetings in East César Chávez, the first neighborhood to be planned, and two of the initial meetings for another process as well as key city council hearings. Observation provided the opportunity to view how political arguments were articulated in the political process and to obtain a first-hand perspective on how alternative discursive framings related to each other in practice (Atkinson \& Hammersley, 1994; Burawoy, Gamson, \& Burton, 1991). Archival research was also obtained pertaining to the character of planning policy in Austin during the 1990s. Key sources were government documents, newspapers, and materials distributed by activist organizations. The purpose of this research component was to develop a contextual understanding of contemporary debates. Information elicited by each of these methods informs the discussion in the following sections.

\section{AUSTIN IN THE 1990S: BOOM AND BIFURCATION}

If, as Agnew (1997) argues, "[i]n a period of rapid political and economic change, political actors can be expected to offer new and, perhaps, competing visions of the relevant geographical scales at which politics should be organized" (p. 100), then Austin is fertile ground for a study of urban politics as an example of the politics of scale. The city is located at the center of a triangular urban region of 15 million people stretching from Dallas-Fort Worth to Houston and San Antonio. It has experienced rapid population growth in the last decade with a $32 \%$ increase in the period 1990 to 1999 and a current metropolitan population over one million. Central to this growth has been the rise of the city's new economy. High technology employment grew by almost $80 \%$ in the 1990 s, far outstripping Austin's major competitors (Boulder-Denver, Raleigh-Durham, Salt Lake City, San Jose, and Seattle) (Greater Austin Chamber of Commerce, 2000). The attraction of Austin for high technology companies is a complex issue. On the one hand, the Dell Computer Corporation is headquartered in the city and since the 1980s has been seen as an icon and catalyst of the city's economic development. On the other hand, interviews with local economic development leaders indicate a long-term development effort beginning in the 1950s that used the city's low cost of living, state government, and the availability of the engineering graduates from the University of Texas to attract industry (see Engelking, 1996). The massive growth in high technology employment since 1995 has also been encouraged by the city's low cost of living and low cost of doing business relative to its competitors. 
The rise of the new economy has exacerbated existing economic and social cleavages. While the median household income is $\$ 42,370$ (the US figure is $\$ 40,816$ ), there is significant poverty in Austin. Approximately $13.09 \%$ of the Travis County population lives in households with incomes below poverty in 1999 compared to $12.7 \%$ for the US as a whole (Sustainability Indicators Project, 2000). Furthermore, the greatest concentrations of poverty are in majority Latino and African American neighborhoods. Housing affordability is also becoming an increasing concern. In the Austin-San Marcos MSA, the percentage of houses priced affordably for a household earning the median income dropped from $62.2 \%$ in 1991 to $57.7 \%$ in 1998 (the national average in 1998 was $65.75 \%$ ). In the 1990s, average wages in high tech fields increased by $\$ 26,500$ while all industry (including high tech) increased by only $\$ 18,000$ (in line with the US average) (Sustainability Indicators Project, 2000). The benefits of Austin's new economy boom seem to be flowing to a small class of people while its deleterious effects are spread to a greater variety of groups and, increasingly, onto a fragile natural environment.

Social and economic bifurcation is expressed clearly in the city's landscape. The karst environment to the west of the city, on the edge of the Texas Hill Country and located on the Edwards Aquifer, from which the city draws its water supply, has been increasingly developed in the last decade. It has become a landscape of hilltop mansions reminiscent of the wealthier parts of southern California. On the other hand, the urban core has grown to be increasingly clogged with traffic, while gentrification has become an increasing concern in low-income inner city neighborhoods. The rapid urbanization described here became an increasing source of tension among various interest groups in Austin during the 1990s. Through this period a coalition of environmentalists, including national organizations such as the Sierra Club, local groups intent on protecting the Hill Country, and other groups, organized around issues of environmental justice and pollution in inner city neighborhoods, engaged in conflict with developers and newly arrived corporations over the future of urban development. During this period, local elections produced what is referred to as a green city council, dominated by Democrats. The council's environmentalist agenda coalesced with a local government bureaucracy heavily influenced by critiques of uncontrolled urban growth. These concerns are reflected in the publications of the city's planning department:

Austin is growing and changing. Austinites throughout the city are enjoying the benefits of the booming economy - more jobs and new businesses, higher wages, and increased property values. However, there is a downside to this remarkable growth - crowded roads, climbing rents and soaring home prices (City of Austin, 2000a, p. 3).

The rapid urbanization of Austin in the 1990s produced four major political and policy problems: population growth, the demands of the high technology firms for industrial and office sites, increased social and economic inequalities, and environmental stress. These rapid changes produced a crisis in the existing policy-making structure that managed land use, infrastructure provision, the natural environment, and led to a number of disputes over development and a growing dissatisfaction with how growth was being managed. In order to mitigate this political crisis and facilitate economic development while preserving Austin's environment, local politicians and planners developed a discursive frame and associated scalar fix. The discursive framing had two initial elements: Austin's policy agencies framed the city's situation in a way that identified the main problem to be addressed as one of urban sprawl. This permitted the solution to the problem to be framed in terms of the management of the built environment and the development of incentive 


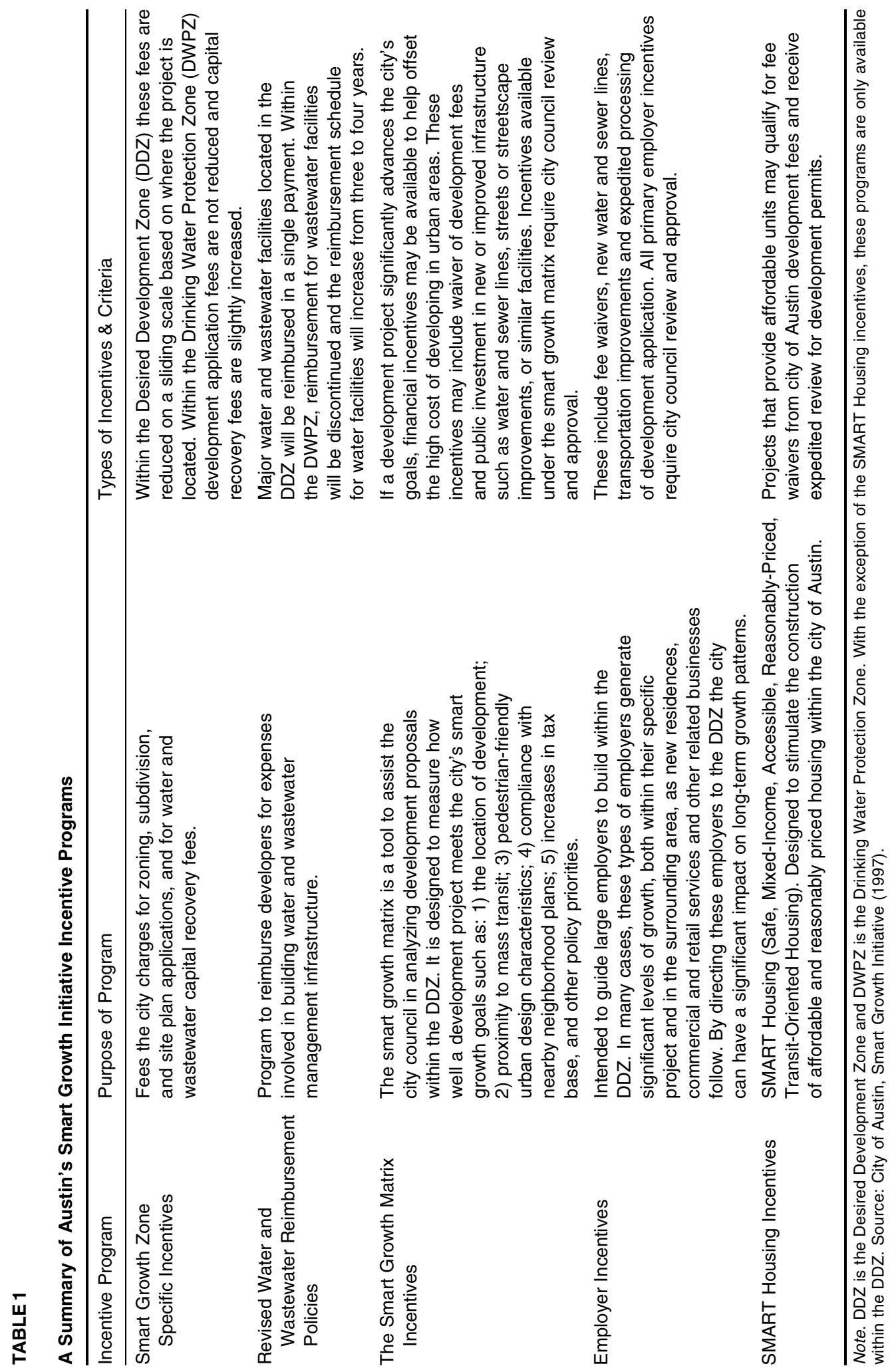


programs that would discourage further development of the city's suburbs in favor of increased development in the city's downtown and surrounding core neighborhoods. This, it was argued, would control and ameliorate the effects of urban sprawl.

In order for these policies to be successful, they needed to be politically tenable. Thus, it was necessary to create growth management policies that would be acceptable to local developers. At the same time, a policy structure that would avert the possibility of neighborhood resistance by promising to give residents the opportunity to mitigate the effects of increased downtown development was also necessary. This aspect of the scalar fix entailed the creation of an entirely new scale of policy-making (the neighborhood planning unit) through which neighborhoods would create zoning categories that would best accommodate new development.

\section{Discursive Framing: State Agencies Defining Problems and Solutions}

In 1997, Austin's planning department produced a study of the city's expansion that showed its northern and western periphery growing significantly in terms of population while the majority of the city's core was seen to be attracting very little new population. This report was taken to represent a larger set of social, environmental, economic, and policy-making challenges for the city. As the planners put it,

[o]ur current pattern of growth, sometimes known as "sprawl," has a number of negative cultural, economic, environmental, and social consequences. In central cities and older suburbs these include deteriorating infrastructure, poor schools, and a shortage of affordable, quality housing. In newer suburban areas these problems may include increased traffic congestion and declining air quality, the absence of a sense of place, and the loss of open space (City of Austin, 1997, p. 1).

In the 1990s, sprawl became a key theme in Austin's urban development politics. The city built its reputation and local economic development policy on its high quality of life. By the mid-1990s, the city was caught on the horns of a dilemma. The successful use of the city's quality of life and its surrounding environment as tools for attracting residents and corporate investment has been considerable. According to several business leaders, however, the resultant economic and geographical expansion threatened to destroy the environmental and socio-economic conditions that were so attractive to high technology employers in the first place.

It is in this context that the organization and management of the built environment has been defined as the primary policy solution to the problems produced by Austin's rapid urbanization. This solution has been articulated through a set of land use policies, referred to as the Smart Growth Initiative, with little direct reference to overarching social structures that shape various groups' interactions with the urban built environment. The initiative has three basic premises: 1) urban growth should be restricted to a Desired Development Zone centered on the city's downtown and growth should be discouraged in a surrounding Drinking Water Protection Zone; 2) smart growth programs can improve quality of life through neighborhood preservation, environmental management, transportation planning, and economic development; and 3) smart growth can improve the city's tax base through efficient public investment and management (City of Austin, 1997). These premises indicate a focus on the location of new infrastructure and development, its impact on environmental quality, the preservation of certain parts of the city, the strategic development of others, and bureaucratic efficiency. These concerns highlight an 
ongoing politics of scale in which Austin's local state agencies and green Democratic politicians engage in the "fusion of a set of ideologies and practices" from a number of scales into a local policy model (Delaney \& Leitner, 1997, p. 97).

Austin's Smart Growth Initiative was, to some extent, influenced by a national-scale discourse on urban policy in the late 1990s. This national focus was articulated in President Clinton's 1999 State of the Union address and the subsequent announcement of the White House's livability agenda (Gore, 1999) that identified rapid, loosely managed urban growth as a crucial policy challenge. Moreover, from its inception in the late 1990s, smart growth in Austin has been an incentive-based, rather than regulatory solution to urban growth (Table 1). While growth management in many parts of the US has been implemented primarily through regulatory means such as growth boundaries and urban service areas (Knaap \& Nelson, 1992; McCann, 1997), Austin's model of smart growth has been set on a path of less regulation. Again, it is possible to identify a cross-scale connection between this policy decision and the national level in the US. The shift away from state coercive power is generally accepted in the national policy arena. Planners in the city contended that this national scale ethos was fused to the urban scale in Austin through concrete examples drawn from Maryland's statewide smart growth initiative.

The choice of an incentive-based policy was also influenced by a history of interactions between Austin's city government and the Texas state legislature and courts. Most important, the degree of power over development given to localities in Texas is less than in other states and the Texas legislature has traditionally been hostile to attempts to curtail development of any sort. In the past this has led to a series of disputes over development between the traditionally liberal and environmentally conscious city of Austin and the traditionally conservative and growth-oriented state of Texas. Planners and economic development leaders believe that because most of these conflicts have resulted in defeat for the city's regulatory efforts to manage growth, the incentive-based Smart Growth Initiative is an attempt to bring the state on board while allowing the city to pursue growth management. A specific type of scale politics can be seen in Austin's strategic adoption of incentive-based smart growth policies. The combination of environmentally oriented growth management principles with business incentives rather than regulations seemed to span diverse political interests at the state and national levels and promise success in managing the built environment. This sort of fusion is central to the social construction of scale because it is an active social process with political effects. Furthermore, it emphasizes Agnew's (1997) point that any scale can only be understood in relation to others.

The success of this political and policy strategy needs to be built on the smooth implementation of smart growth goals through local state institutions. This aspect of the Initiative was influenced by the recent history of planning politics at the city level. Austin's longstanding comprehensive planning model was discredited during the 1990s as fractious disputes over urban growth pitted developers, environmental activists, neighborhood groups, and planners against each other in a decision-making framework that encouraged each side to resist compromise. It also encouraged the loser in these arguments to appeal to the state legislature and the courts. This model became unworkable by the middle of the 1990s and as a result the city council empanelled 22 people, mostly lay planners or citizen advisors, to identify problems with the current planning model and propose changes (Citizens' Planning Committee, 1995, 1996). The committee argued strongly for a reorganization of comprehensive planning so that it would be based on "integrative community plans created through neighborhood participation" and for the city to "make use of economic incentives, infrastructure and investment to coordinate and 
encourage development consistent with its vision" (1995, p. 3). These recommendations were influenced not only by the negative experience of recent local planning procedures but also by developing trends in participatory planning around the country. They reinforced the city council's resolve to create a policy solution oriented toward the built environment and framed this new policy orientation within the neighborhood scale by emphasizing local face-to-face participatory decision-making.

The neighborhood planning model that developed in Austin as part of smart growth can be understood as the product of a particular discursive framing of reality that drew upon ideologies, practices, and experiences at a number of scales to construct what appeared to be a feasible policy solution to the problems of rapid urbanization. In the remainder of the article, I discuss the scalar fix that accompanied this new discursive framing, highlight the character of the newly constructed scale of neighborhood planning, and outline the politics of scale that emerged around it. The political debates and contests revolved largely around various actors' attempts to justify, utilize, or problematize this new discursive framing.

\section{A New Scalar Fix: Austin's Neighborhoods First Program}

Neighborhood planning involved dividing Austin's urban core into 50 city-designated neighborhood planning areas. This new territorial organization promised a scalar fix that would facilitate capital investment in the downtown and its surrounding neighborhoods by providing predictability and opportunities to buy into the plan across a broad spectrum of interests in ways that the traditional comprehensive planning model did not allow. Face-to-face collaboration and the creation of new visions were crucial components of this new process:

The neighborhood planning process engages residents, businesses, property owners, city departments, community organizations such as neighborhood associations and other community groups.... The goal of neighborhood planning is for diverse interests to come together and develop a shared vision for their community (City of Austin, 2000a, p. 1).

Of course, the creation of any new scale of policy-making brings with it a reconfigured politics of scale that presents a whole new set of problems for governance. This was evident in the early attempts to reshape comprehensive planning from the neighborhood scale up.

\section{The East César Chávez Neighborhood Planning Process}

The East César Chávez neighborhood, located in East Austin across an interstate highway from downtown, was one of the first to be chosen for neighborhood planning. It is a predominantly Latino neighborhood with $83 \%$ of residents defined by the US census as Hispanic (Austin's Hispanic population is 23\%). It is also one of the poorest areas in the city with a median household income (1990) of only $\$ 14,329$. Furthermore, $66 \%$ of its residents are renters (Austin's rental rate is 59\%). It has been the focus of struggles over environmental justice and gentrification led by a coalition of activist organizations including the Council of East Austin Neighborhood Associations (El Concilio) and PODER (People Organized in Defense of Earth and her Resources), an organization largely focused on environmental justice issues. The way that neighborhood 
planning proceeded in East César Chávez suggests that the swift completion of all 50 plans in the urban core may be overly optimistic. PODER and El Concilio opposed neighborhood planning because they saw it as undermining their position as representatives of the neighborhood by creating a new structure of decision-making involving people not affiliated with these organizations. They also claimed that the planning process was not intended to help existing residents but to create a new set of planning guidelines that would facilitate gentrification and the removal of longtime residents of color. Planners saw the new procedures as the best way to prepare for inevitable development in the neighborhood as the adjacent downtown expanded and other smart growth policies discouraged suburban development, pushing it back into the urban core. Furthermore, groups in the neighborhood who supported neighborhood planning argued that the opposition was based on an insular and backward-looking view of what the community was and what the neighborhood should be. Before elaborating on these issues, I briefly describe the plan that was eventually produced by this process, one that PODER and El Concilio opposed vehemently at every stage.

The East César Chávez neighborhood plan was developed from late 1997 until May 1999 when it was adopted by ordinance. The main theme of the final plan was the rezoning of significant parts of the neighborhood, especially the main streets running through it from downtown, for mixed uses. Austin's neighborhood plans only deal with zoning, transportation, and design issues. They have little power to do more than reorganize zoning categories. Furthermore, the city is under no obligation to carry out recommendations of the plans because local residents are required to sign a memorandum of understanding that states, "[w]hen adopted, neighborhood plans will provide direction [italics added] for City programs.... Neighborhood plans also help guide [italics added] the decisions of City Boards and Commissions" (City of Austin, 2000b, p. 1). If the lay planners refuse to accept these terms, city staff is pulled out until the disagreement is overcome. Despite these limitations, those who wrote the plan saw it as encouraging and maintaining the vitality of street life and community ties in the neighborhood. As they put it, East César Chávez should "remain a place where people sit on their front porches and wave to their neighbors or lend a helping hand, or where working people, the elderly and young families can afford to live" (City of Austin, 1999, p. 1). Opponents saw the plan as encouraging gentrification and other development spilling over from the rapidly growing downtown by permitting a much greater range of uses and types of housing than under existing zoning (Almanza, 2000; Trower, 1998). By the end of 2000, the zoning recommendations in the plan had been adopted by the city. Final adoption occurred only after another round of bitter arguments, this time in the city council chamber and not in the neighborhood itself.

\section{A Politics of Scale: Framing Space and Time in Neighborhood Planning}

Scales and scalar fixes are continually contested, often through the articulation of contradictory framings and the outcomes of this politics of scale are always contingent. In East César Chávez, the initiation of a new form of collaborative decision-making processes undermined El Concilio and PODER's role as the major advocates for the residents in their dealings with local state agencies. The rescaling created a new terrain on which others had a more firm footing for advocating alternative visions of the neighborhood's future. On the other hand, the ideal of collaboration and consensus building at the heart of the creation of the neighborhood planning process meant that organized and vociferous opposition to and abstention from the process severely hampered the ability of 
planners to facilitate decision-making. As a result, the plan took much longer to complete than had been anticipated and questions were raised about its legitimacy as a document representing the will of the residents and business people of the neighborhood. The shift of powers and responsibilities from one scale to another was complicated. Instead, the process of rescaling, as represented in the open forums of the neighborhood planning process, provided the opportunity for new forms of political argumentation to contest the discursive framing and ultimately identified the neighborhood as the appropriate territorial unit in which planning decisions should be made.

\section{Dividing and Ordering Space and Time}

When the new neighborhood planning process was announced, PODER and El Concilio formed the El Pueblo Coalition (EPC) for the purpose of redefining the area considered a neighborhood for planning purposes. A neighborhood activist explained that the area proposed by EPC covered a substantial part of East Austin because this is where the coalition's constituency of mainly low-income Latinos lives. City planning staff resisted EPC's proposal, maintaining that the area was too large to be planned in the manner dictated by the Neighborhood Planning guidelines. From the EPC's perspective, this refusal signified a continued exclusion of their constituency from power. As one member of the coalition argued,

In order to empower our communities and build effective leadership, we must set our own agenda and address issues of environmental, social, and economic justice as basic human rights. We must demand the right to participate in those policy processes that impact our daily lives.

For EPC the neighborhood planning initiative was disempowering and exclusionary for two reasons. First, the identification of the neighborhood's major problems and how they might best be solved had already been established in terms of the built environment, not in terms of various rights. Of course, other political actors felt differently. Another neighborhood activist not associated with EPC argued in an interview that she believed that the building of new retail outlets in the neighborhood, especially chain and franchise outlets, would improve the place and the quality of life of its residents. A planner who was heavily involved in the neighborhood plan strongly stated that her reason for becoming a planner and for being involved in this initiative was because she believed that her work could promote social and economic justice. Second, EPC believed that their community leadership was undermined by planners' refusal to consider a large part of East Austin as one neighborhood. Amid accusations of divide-and-rule tactics, the planners engaged with other neighborhood residents with whom they maintained relations that were more cordial. These people formed the East César Chávez Leadership Team (ECCLT), an officially recognized coordinating body for the new planning process. The ECCLT and the planning staff agreed upon the more limited definition of the neighborhood. This agreement led EPC to argue that the ECCLT was an illegitimate group of outsiders and self-interested business owners who were acting to exclude the ordinary people of the neighborhood from the new planning process.

This accusation, and the dispute over the definition of the neighborhood that precipitated it, can be understood as stemming from conflicting understandings of how a particular place like East Austin is situated in scalar hierarchies. The dispute also reflects the historical and social processes that produce place-based identities. In the EPC's 
framing of the neighborhood scale, the right to engage in the reshaping of the place can only come through long-term residence, family connections, and involvement in previous struggles. As one resident put it, the ECCLT is

not a representative body of what I consider the heart and soul of East Austin. What I'm talking about is the people who have grandmothers here, who have been members of the churches for many years, who have fought the wars, who were instrumental in closing down the tank farms [a major success in PODER's environmental activism] (Moscoso, 1997, p. B1).

The quote illustrates an attempt to frame the planning process in terms of both spatial and temporal scale. One must live in the neighborhood (not merely own a business there as the neighborhood planning initiative allows) and must have lived there, or be from a family that has lived there, for more than just a few years. This dual scalar framing resonates with contemporary geographers understandings of how society and space are interconnected. Soja (1985), for instance, argues "[s]patiality and temporality, human geography and human history, intersect in a complex social process" (p. 100) in order to shape social life. Therefore, discursive framings of these two forms of scale can have significant political power and material effects.

For this reason, members of the ECCLT and the city planners vigorously contested EPC's framing of the political conflict. A member of the ECCLT argued,

I may not sleep here but I've been here for 35 years. How am I not part of the community... The problems between the groups could ruin what started as a positive, enthusiastic effort. I hope all this petty politicking and bickering has not sapped all that energy (Moscoso, 1997, p. B1).

This sort of argument was coupled with an assertion that the EPC activists were living in the past (a description repeated by many) in their criticism of changes in the neighborhood.

These conflicting and competing framings indicate that assumptions about who belongs to a place and who is a valid representative of its interests were not easily legitimated by a formal city planning process. Rather, the creation of neighborhood planning as a new scale of policy-making also created obstacles to the effective functioning of planning in the city as a whole. Specifically, by creating a new scale the city council indicated that the standard scales in which urban policy-making takes place were not immutable but open to political argumentation and reframing. This led to a politics of scale that quickly came to dominate Austin's planning process.

\section{Interconnections in Space and Time}

The first aspect of the politics of scale in Austin revolves around conflicting attempts to set scalar boundaries and limits both on the territory to be defined as a neighborhood for planning purposes and on the appropriate amount of time a resident needs to be in a neighborhood before being able to speak for it. The second aspect entailed an opposite, but nonetheless related, political strategy on the part of EPC. The coalition argued against the fundamental scalar premise of the neighborhood planning initiative. They contested the idea that shifting planning power and political discussion down from the city level to the neighborhood was the best way to overcome the problems associated with the rapid 
downtown development caused by growth management policies on the city's periphery. Instead, the EPC constructed a political argument that emphasized interconnections across scales. Again, the scales in question here were both spatial and temporal.

The contested framing of temporal scale centered on very different interpretations of when and how Austin's most pressing social and land use problems had emerged. As suggested above, the standard interpretation is that the decade of the 1990s, with its boom in high tech employment and growth in population, was when Austin's well-planned economic expansion started to encounter increasing internal crises. This, then, is the reference point for most city politicians and for the Smart Growth Initiative. Most discussions of Austin's planning problems tend not to refer back much further than the early 1990s. The EPC, on the other hand, argued that since the beginning of the twentieth century, East Austin and its ethnic minority inhabitants had been the object of discriminatory zoning policies. These were institutionalized in the city's 1928 Master Plan, which recommended the location of minority houses, parks, and schools next to heavy industry in the eastern part of the city. The legacy of these policies is still felt today, EPC argued, due to a lack of subsequent attention to its effects by the city's contemporary planning agencies (Alford, 2000). Organizations like PODER and El Concilio constructed a politics of temporal scale that refused to adhere to the "pre-1990/post-1990" framework and instead insisted on political argumentation about the present and future that drew elements from the last century of urbanization in central Texas, including its racialized character. In the words of one neighborhood activist, "Poor or racist land use policies are the core cause of ... injustices for communities of color... It's a battle that people of color, time and again, lose to urban renewal, to crime waves that are sweeping their neighborhoods, to gentrification, and to the development or abandonment of property."

The attempt to create connections across temporal scales for the purpose of political argumentation worked in tandem with a politics of spatial scale that emphasized its interconnected or networked character (Agnew, 1997; Cox, 1998a; Murdoch \& Marsden, 1995). While the city council partially shifted its attention from the citywide level to that of the neighborhood, the EPC's political strategy was to call the efficacy of the neighborhood solution into question by talking about the space of the city as interconnected socially, economically, and environmentally rather than divided into discrete neighborhoods. One activist argued that "[n]ot only does the suburban sprawl destroy the natural resources of the areas to which the sprawl has spread, but it also erodes the resource base on which cities were built in the first place." The following passage from the PODER newsletter sets out EPC's critique in explicitly spatial terms:

\footnotetext{
While smart growth strategies are being used to constrain suburban sprawl, this could push homebuyers and investors back to central cities, driving up rents and displacing long-time residents and small business owners. This is exactly what is happening in East Austin!. . .East Austinites are finding out that [Neighborhood Planning] never really was about planning our neighborhoods - it was about rezoning our neighborhoods and the beginning of displacement of generations of East Austinites and the gentrification of our neighborhoods.... Developers and Speculators have the money to do it and are at the gateways of our communities just awaiting the new zoning approval (Almanza, 2000, p. 7).
}

If the case of contemporary Austin is any indication, the contestation of scale production in US cities is a complex and often seemingly contradictory process. EPC's politics entailed attempts to bound spatial and temporal scale in very specific ways for the purpose 
of maintaining their central role in the representation of East Austin to the city council. At the same time, a parallel strategy sought to break down boundaries set by the city by constructing representations of Austin's geography and history that emphasized extensive connections. In a context of rescaling and restructuring where the political opportunities and constraints are relatively fluid and open to redefinition through political argumentation, these seemingly contradictory political strategies may be directed toward a common purpose. In the case of neighborhood planning in East César Chávez, the purpose of the EPC was to destabilize the new scalar fix instituted by the local state. This objective was only partially successful, at best. It certainly slowed the process of neighborhood planning, but in the end the plan was adopted. Nonetheless, the continued questioning of neighborhood planning and smart growth by EPC suggests that spatial-temporal scale, defined either as division or as interconnection, will remain a significant theme in ongoing urban politics.

\section{CONCLUSION}

In this article, I presented an analysis of urban politics informed by a burgeoning literature in geography that sees scale as a powerful discursive frame. Strategies of framing can legitimize political action and facilitate certain forms of economic development, social redistribution, and governance. Two key concepts from this literature (scale as a discursive frame and the notion of the scalar fix) inform the analysis. When approached in these terms, the case of neighborhood planning in Austin resonates with three prominent arguments that characterize the constructionist literature on scale: 1) the politics of scale, including urban politics, is constituted by discursive practices that attempt to shape a particular mental map or world view that is persuasive and politically powerful; 2) processes occurring at a particular scale can only be adequately understood when considered in relation to other scales; and 3) as scalar hierarchies are reorganized, the associated politics are also reworked with unpredictable consequences.

In the case of Austin, policies related to growth management and infrastructure provision were seen to be increasingly crisis-ridden in the 1990s as they came under pressure from economic expansion and rapid population growth. This crisis threatened the ability of local state institutions to manage the city's space economy while maintaining necessary political legitimacy. In response to this crisis, a new discursive framing was developed in the late 1990s. This framing identified the city's major problem in terms urban sprawl and the best solution in terms of new strategies for managing the built environment, including a move away from the urban scale. This framing facilitated the implementation of a specific scalar fix in which incentive policies aimed at mitigating growth on the city's periphery and encouraging development in and around the downtown were accompanied by the creation of a new scale of neighborhood planning. This new scale was intended to prepare inner city neighborhoods for new development in the city center and, therefore, aid the success of policies aimed at curtailing peripheral growth by giving developers an attractive alternative to suburban development. The neighborhood scale of planning also had a political function. By creating this scale and framing neighborhood planning in terms of participatory decision-making, the city's politicians hoped to mitigate opposition to downtown development by incorporating diverse interests into the policy-making process.

Nonetheless, since its inception in 1997, the Neighborhood Planning Initiative has been the object of opposition in some neighborhoods and the outcomes of the creation of this new scale have been far from predictable. The politics surrounding this new policy framework have been explicitly scalar. Just as the solution to sprawl was framed in terms of the 
creation of a new scale, those opposed to the city's development policies have built their opposition on a complex set of scalar discourses that seek to create a much different mental image of the city's geography and history. As their arguments suggest, it is impossible to understand the politics around neighborhood planning in Austin without relating it to processes that are taking place or have occurred at other spatial and temporal scales. Furthermore, the process of creating what was hoped to be a new scalar fix in Austin provided the opportunity for these types of scalar discourses to be articulated in new ways in the city's political process. This ultimately produced unpredictable results for both advocates and opponents of neighborhood planning.

The Austin case clearly resonates with the key arguments contemporary geographers make about scale. These arguments have implications for the study of urban politics beyond the discipline of geography since, according to Agnew (1997), "politics is intrinsically a spatialized activity, even when nobody notices" (p. 118). The case study also suggests that geographers must not become too narrowly focused on spatial scale in their analysis of politics. The longstanding concepts of space and time in geography, in which social life is understood to be historically and geographically constituted, allow us to see that in urban politics, strategic framings of reality often define spatial and temporal scales in combination with and in reference to each other.

This understanding of urban politics as a politics of scale also has implications for public policy. As neighborhood-based collaborative planning processes become more popular in the US, it is crucial to be aware of the difference that scale makes in the politics of policy-making. When a policy-making process is rescaled it is fundamentally changed, as are the scales to and from which it is moved. Furthermore, the familiar rhythm of politics that develops over a long period in reference to one stable policymaking scale is disrupted and reconfigured through the institution of a new scalar fix. In the case of urban planning, these points mean that planners cannot necessarily be expected to engage in or deal with political argumentation in ways that they have traditionally been trained because that training may not deal with the sorts of scalar arguments that were, for instance, exhibited in Austin.

In this case, planners were confronted with arguments against their zoning proposals that drew from longstanding grievances about racial discrimination and that were predicated upon a very different understanding of what it meant to be an insider or an outsider in a particular neighborhood. While the planners I interviewed and observed in Austin were sensitive to these arguments (and in some cases agreed with them), the structure of planning practice (in which their remit extended no further than land use issues) left them frustrated and with very little leeway in which to accommodate arguments about long histories of inequality. This is not, I believe, the fault of the individual planners. Rather, it presents a challenge to those who hope to reshape urban policymaking along collaborative and smart growth lines. Such changes must be accompanied by a recognition that new sets of claims will be made on state bureaucrats who may be structurally unable to deal with them. Perhaps a successful rescaling of planning to the neighborhood level needs a complete reshaping of the institutional framework of local governance so that land use professionals are only one group of agents who are empowered to facilitate neighborhood planning. In the future, they may have to be accompanied by social service and economic development professionals who are able to affect real change. If smart growth and collaborative planning continue to be implemented solely in reference to land use issues, even as they open up the decision-making process to a wider array of interests and opinions, they are likely to experience a great deal of implementation problems, many of which will be extremely difficult to overcome. 
ACKNOWLEDGEMENTS: The research upon which this article is based was funded by a grant from the Ohio State University Research Foundation. I would like to thank the Department of Geography at the University of Texas, Austin for its hospitality and the planners and activists with whom I interacted for their generosity and time. Thanks to Richard Healy for his research assistance and to Deb Martin, Mark Purcell, Jason Hackworth, Bob Lake, and two anonymous reviewers for valuable comments on earlier drafts. All arguments and conclusions are entirely my responsibility.

\section{REFERENCES}

Agnew, J. (1997). The dramaturgy of horizons: Geographical scale in the "reconstruction of Italy" by the new Italian political parties, 1992-95. Political Geography, 16, 99-122.

Alford, A. (2000, December 15). East Austin zoning changes approved: Industrial-use limits, proposed in East Cesar Chavez plan, pass after battle. Austin American-Statesman, p. B7.

Almanza, S. (2000, Summer). Displacement and gentrification. Xinachtli en PODER, 7.

Atkinson, P., \& Hammersley, M. (1994). Ethnography and participant observation. In N. K. Denzin \& Y. S. Lincoln (Eds.), The handbook of qualitative research, (pp. 248-261). Thousand Oaks, CA: Sage.

Barnes, T. J., \& Duncan, J. S. (1992). Introduction: Writing worlds. In T. J. Barnes \& J. S. Duncan (Eds.), Writing worlds: Discourse, text and metaphor in the representation of landscape, (pp. 1-17). New York: Routledge.

Brenner, N. (1998a). Between fixity and motion: Accumulation, territorial organization and the historical geography of spatial scales. Environment and Planning D: Society and Space, 16, 459-481.

Brenner, N. (1998b). Global cities, glocal states: Global city formation and state territorial restructuring in contemporary Europe. Review of International Political Economy, 5, 1-37.

Brenner, N. (2000). The urban question as a scale question: Reflections on Henri Lefebvre, urban theory and the politics of scale. International Journal of Urban and Regional Research, 24, 361-78.

Burawoy, M., Gamson, J., \& Burton, A. (1991). Ethnography unbound: Power and resistance in the modern metropolis. Berkeley: University of California Press.

Checkoway, B. (1984). Two types of planning in neighborhoods. Journal of Planning Education, and Research, 3, 102-109.

Citizens' Planning Committee. (1995). Citizens' planning committee report. Austin: City of Austin.

Citizens' Planning Committee. (1996). From chaos to common ground: A blueprint for Austin and surrounding communities. Austin: City of Austin.

City of Austin. (1997). Smart growth guide: Enhancing Austin's quality of life neighborhood by neighborhood. Austin: City of Austin Planning, Environmental and Conservation Services Department.

City of Austin. (1999). The East César Chávez neighborhood plan: An amendment to the city of Austin's comprehensive plan. Austin: East César Chávez Neighborhood Planning Leadership Team. Austin, TX. Available: http://www.ci.austin.tx.us/zoning/downloads/ecc_np.pdf [January 2003].

City of Austin. (2000a). Neighborhood planning workbook. Austin: Planning, Environmental and Conservation Services Department. Austin, TX.

City of Austin. (2000b). Cherrywood Neighborhood Planning Team and the City of Austin neighborhood planning memorandum of understanding. Austin: Planning, Environmental and Conservation Services Department. Austin, TX

Cox, K. R. (1997). Governance, urban regime analysis, and the politics of local economic development. In M. Lauria (Ed.), Reconstructing urban regime theory: Regulating urban politics in a global economy (pp. 99-121). Thousand Oaks, CA: Sage.

Cox, K. R. (1998a). Spaces of dependence, spaces of engagement and the politics of scale, or: Looking for local politics. Political Geography, 17, 1-24.

Cox, K. R. (1998b). Representations and power in the politics of scale. Political Geography, 17, 41-44.

Cox, K. R. (2002). Territory, divisions of labor, and the new politics of scale. In A. Herod \& M. Wright (Eds.), Geographies of power: Placing scale. Cambridge, MA: Blackwell. 
Cox, K. R., \& Mair, A. (1988). Locality and community in the politics of local economic development. Annals of the Association of American Geographers, 78, 307-325.

Cox, K. R., \& Mair, A. (1989). Urban growth machines and the politics of local economic development. International Journal of Urban and Regional Research, 13, 137-146.

Dear, M. J. (1986). Postmodernism and planning. Environment and Planning D: Society and Space, 4, 367-384.

Dear, M. J. (1989). Survey 16: Privatization and the rhetoric of planning practice. Environment and Planning D: Society and Space, 7, 449-462.

Delaney, D., \& Leitner, H. (1997). The political construction of scale. Political Geography, 16, 93-97.

Engelking, S. E. (1996). Austin's opportunity economy: A model for collaborative technology development. Annals of the New York Academy of Sciences, April, 29-47.

Fainstein, S. S., Fainstein, N. I., Hill, R. C., Judd, D., \& Smith, M. P. (Eds.). (1987). Restructuring the city, the political economy of urban development. New York: Longman.

Filion, P. (1996). Metropolitan planning objectives and implementation constraints: Planning in a postFordist and postmodern age. Environment and Planning A, 28, 1637-1660.

Greater Austin Chamber of Commerce. (2000). The state of the regional economy. Austin, Texas: Greater Austin Chamber of Commerce.

Gregory, D. (1994). Geographical imaginations. Cambridge, MA: Blackwell.

Harvey, D. (1989). From managerialism to entrepreneurialism: The transformation of urban governance in late capitalism. Geografiska Annaler, 71B, 3-17.

Helling, A. (1998). Collaborative visioning: Proceed with caution! Results from evaluating Atlanta's Vision 2020 project. Journal of the American Planning Association, 64, 335-349.

Jessop, B. (1994). Post-Fordism and the state. In A. Amin (Ed.), Post-Fordism: A reader. Cambridge, MA: Blackwell.

Jonas, A. E. G. (1994). United States urban policy: A question of scale? Urban Geography, 15, 395-405.

Jonas, A. E. G., \& Ward, K. G. (2002). A world of regionalisms: Towards a US-UK urban and regional policy framework comparison. Journal of Urban Affairs, 24, 377-401.

Jones, B. (1990). Neighborhood planning: A guide for citizens and planners. Chicago: Planners Press.

Knaap, G., \& Nelson, A. C. (1992). The regulated landscape: Lessons on state land use Planning from Oregon. Cambridge, MA: Lincoln Institute of Land Policy.

Lake, R. W. (1994). Negotiating local autonomy. Political Geography, 13(5), 423-442.

Lake, R. W. (1996). Volunteers, NIMBYs, and environmental justice: Dilemmas of democratic practice. Antipode, 28, 160-174.

Logan, J. R., \& Molotch, H. (1987). Urban fortunes: The political economy of place. Berkeley: University of California Press.

Marston, S. A. (2000). The social construction of scale. Progress in Human Geography, 24, 219-242.

MacLeod, G., \& Goodwin, M. (1999). Space, scale and state strategy: Re-thinking urban and regional governance. Progress in Human Geography, 23, 503-527.

McCann, E. J. (1997). Where do you draw the line? Landscape, texts, and the politics of planning. Environment and Planning D: Society and Space, 15, 641-661.

McCann, E. J. (2001). Collaborative visioning or planning as therapy? The politics of public-private policy-making. Professional Geographer, 53, 207-218.

McGuirk, P. (1994). Economic restructuring and the realignment of the urban planning system: The case of Dublin. Urban Studies, 31, 287-308.

Moscoso, E. (1997, November 28). Split slows neighborhood planning: East Austin divided on delegates to impending city guideline sessions. Austin American-Statesman, p. B1.

Murdoch, J., \& Marsden, T. (1995). The spatialization of politics: Local and national actor spaces in environmental conflict. Transactions of the Institute of British Geographers, NS 20, 368-380.

Myers, D., \& Kitsuse, A. (2000). Constructing the future in planning: A survey of theories and tools. Journal of Planning Education and Research, 19, 221-231.

Nash, K. (2000). Contemporary political sociology: Globalization, politics, and power. Cambridge, MA: Blackwell. 
Oregon Visions Project. (1993). A guide to community visioning: Hands-on information for local communities. Portland, OR: Oregon Chapter, American Planning Association.

Peterman, W. (2000). Neighborhood planning and community-based development: The potential and limits of grassroots action. Thousand Oaks, CA: Sage.

Shipley, R., \& Newkirk, R. (1999). Vision and visioning in planning: What do these terms really mean? Environment and Planning B: Planning and Design, 26, 573-591.

Smith, N. (1992). Contours of a spatialized politics: Homeless vehicles and the production of geographical scale. Social Text, 33, 55-81.

Smith, N. (1993). Homeless/global: Scaling places. In J. Bird (Ed.), Mapping the futures (pp. 87-119). London: Routledge.

Snow, D., \& Benford, R. (1992). Master frames and cycles of protest. In A. Morris \& C. Mueller (Eds.), Frontiers in social movement theory (pp. 133-155). New Haven, CT: Yale University Press.

Soja, E. (1985). The spatiality of social life: Towards a transformative retheorization. In D. Gregory \& J. Urry (Eds.), Social relations and spatial structures (pp. 90-122). London: Macmillan.

Stoker, G. (1995). Regime theory and urban politics. In D. Judge, G. Stoker, G., \& H. Wolman (Eds.), Theories of Urban Politics (pp. 54-71). London: Sage.

Stone, C. N. (1989). Regime politics: Governing Atlanta, 1946-1988. Lawrence: University of Kansas Press.

Sustainability Indicators Project of Hays, Travis, and Williamson Counties. (2000). Central Texas indicators 2000: A report on the economic, environmental, and social health of the Central Texas region. Austin, Texas: Sustainability Indicators Project, University of Texas, Urban Issues Program.

Swyngedouw, E. (1997). Neither global or local: "Globalization" and the politics of scale. In K. R. Cox (Ed.), Spaces of globalization: Reasserting the power of the local (pp. 137-166). New York: Guilford.

Tarrow, S. (1992). Mentalities, political cultures, and collective action frames: Constructing meanings through action. In A. Morris \& C. Mueller (Eds.), Frontiers in social movement theory, (pp. 174-202). New Haven, CT: Yale University Press.

Taylor, P. J. (2000). World cities and territorial states under conditions of contemporary globalization. Political Geography, 19, 5-32.

Trower, T. (1998, June 21). Rift bogs down neighborhood plan: Interest groups divided in early stages of city's East César Chávez experiment. Austin American-Statesman, p. B1.

Walzer, N. (1996). Common elements of successful programs. In N. Walzer (Ed.), Community strategic visioning programs (pp. 183-198). Westport, CT: Praeger.

Wilson, D., \& Wouters, J. (2002). Space and growth discourse: The restructuring of America's rust belt cities. Journal of Urban Affairs, 25(2).

Winter, I., \& Brooke, T. (1993). Urban planning and the entrepreneurial state: The view from Victoria, Australia. Environment and Planning C: Government and Policy, 11, 263-278.

Wolman, H., \& Goldsmith, M., (1992). Urban politics and policy: A comparative approach. Cambridge, MA: Blackwell.

Woodmansee, J. (1994). Community visioning: Citizen participation in strategic planning. Washington, DC: International City/County Management Association. Management Information Service. 